\title{
AN APPARENT SPECIFIC DYNAMIC ACTION IN MYTILUS EDULIS L.
}

\author{
B. L. BAYNE AND C. SCULLARD \\ Institute for Marine Environmental Research, Citadel Road, Plymouth PL1 3DH
}

(Figs. 1-4)

\begin{abstract}
Rates of oxygen consumption and filtration by Mytilus edulis increased immediately following feeding. Filtration rates then declined to pre-feeding values within 8-16 h. When the food was Tetraselmis suecica, oxygen consumption declined non-linearly to the pre-feeding level within 28-32 h. This decline in oxygen consumption was resolved into two components, the first of which was coincident in time with changes in filtration rate, the second of which coincided with a marked increase in rates of ammonia excretion. We conclude that the first component in oxygen consumption decline represents the mechanical cost of feeding, and amounts to $24 \%$ of the energy available in the ingested ration; the second component represents the specific dynamic action of the ration (or the physiological cost of feeding) and amounts to $4 \%$ of the energy in the ingested ration. When the food was Phaeodactylum tricornutum, there was no detectable specific dynamic action.
\end{abstract}

\section{INTRODUCTION}

The results of experiments recorded by Bayne \& Scullard (1977) confirmed earlier studies (Bayne, 1973) in describing a decline in the rate of oxygen uptake $\left(\dot{V}_{\mathrm{O}_{2}}\right)$ by Mytilus edulis during starvation, eventually reaching a steady-state value, called the standard rate of oxygen consumption. Earlier experiments had also shown that if such starved mussels were fed, oxygen uptake increased rapidly to a high level called the active rate of oxygen consumption (Thompson \& Bayne, 1972; Bayne, Thompson \& Widdows, 1973). Some of this increase in metabolic rate is undoubtedly due to an increased filtration rate that is stimulated by the presence of food (the 'mechanical cost of feeding' discussed by Bayne et al. 1976), and part is due to the 'physiological costs of feeding', which includes energy utilized in digestion and assimilation of the food, and energy that is lost during deamination and other catabolic processes that accompany digestion (Warren \& Davis, 1967). Increases in metabolic rate associated with feeding have been called the specific dynamic action (SDA) of the ration (see Harper, 1971, for a discussion) or the apparent SDA (Beamish, 1974), and they have been related to aspects of protein metabolism (Krebs, 1964). This paper describes the results of some experiments designed to examine the relationships between SDA and ammonia excretion in Mytilus edulis $\mathrm{L}$.

\section{MATERIAL AND METHODS}

Mytilus edulis were collected from the River Lynher, near Plymouth. Twenty-two mussels were kept in the laboratory, without food, for between 19 and 30 days, at field-ambient temperature $\left(12-15{ }^{\circ} \mathrm{C}\right)$. Individuals were then placed in glass respirometer flasks and, after a period of between 1 and $6 \mathrm{~h}$ allowed for stabilization, their rates of oxygen consumption and ammonia excretion determined by sealing the flask for $1 \mathrm{~h}$ and measuring the oxygen tension in the water continuously, and the ammonia-nitrogen $\left(\mathrm{NH}_{4} \cdot \mathrm{N}\right)$ content at the beginning and end of this period 
(Bayne \& Scullard, 1977). Ammonia-N was measured using a modification (Grasshoff \& Johannsen, 1972) of a method originally described by Solorzano (1969). For some animals filtration ( = feeding) rate was also measured at this time, using the procedure described by Thompson \& Bayne (1972). After these initial measurements, which were used to describe the pre-feeding rates of oxygen consumption, ammonia- $\mathrm{N}$ excretion and feeding, a suspension of algal cells was introduced into the respiration chamber for one hour only. Cell counts (by Coulter Counter) were used to determine the number of cells made available to the animal, and the animal's rate of feeding. Determinations of oxygen consumption and ammonia- $\mathrm{N}$ excretion were also made, as before, for up to $30-36 \mathrm{~h}$ after feeding, to determine the post-feeding rates. Of the 22 animals treated in this way, 15 received Tetraselmis suecica, and 7 received Phaeodactylum tricornutum, as food.

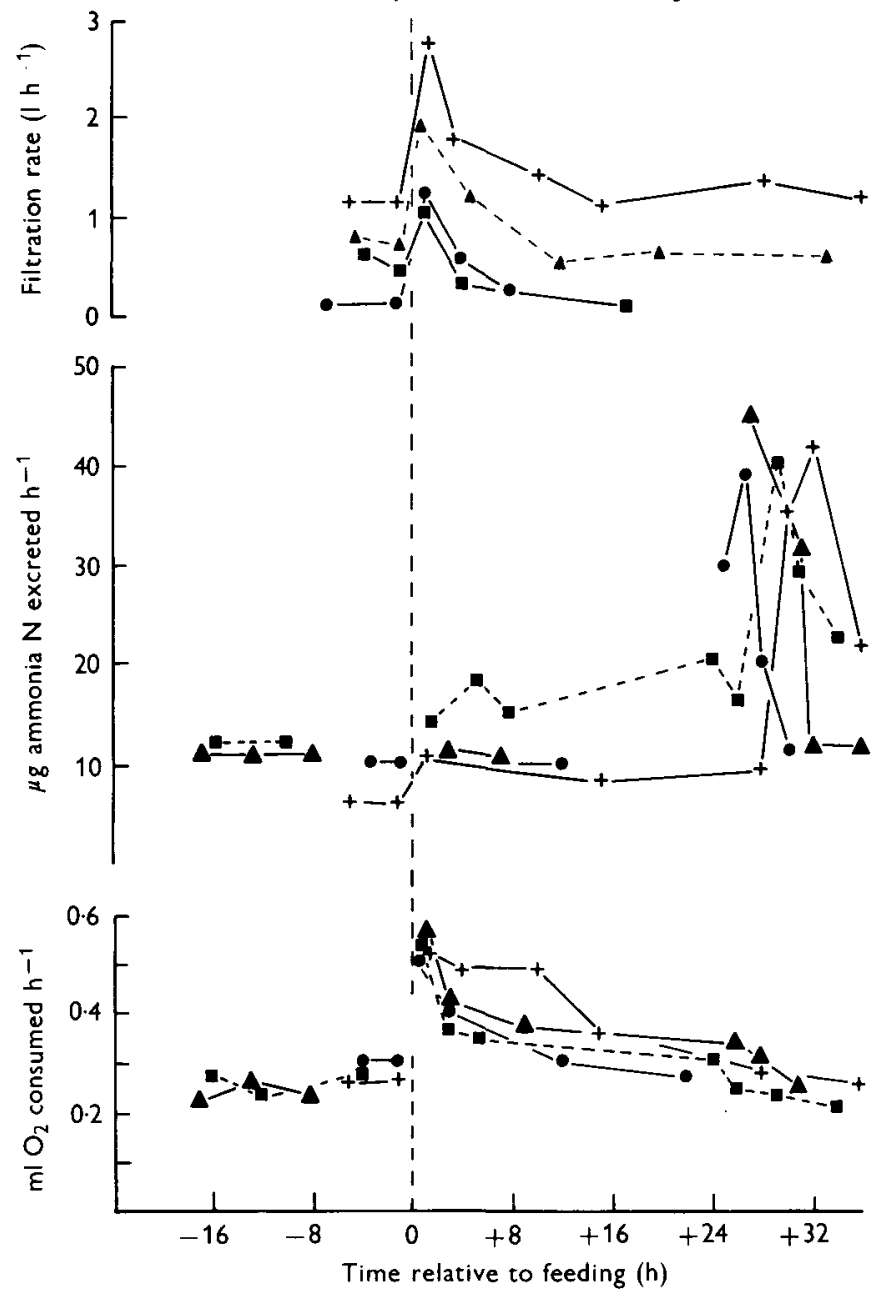

Fig. 1. Rates of oxygen cunsumption ( $\left.\mathrm{ml} \mathrm{O}_{2} \mathrm{~h}^{-1}\right)$, ammonia-N excretion $\left(\mu \mathrm{g} \mathrm{NH}_{4} \cdot \mathrm{N} \mathrm{h}^{-1}\right)$ and filtration ( $\left(1\right.$ water $\left.\mathrm{h}^{-1}\right)$ in four individual mussels $(M$. edulis) which were starved for some days and then fed (dashed line) for $1 \mathrm{~h}$ with cells of Tetraselmis suecica.

\section{RESULTS}

In 17 of the total of 22 experiments, the rate of oxygen consumption increased immediately after feeding and then declined non-linearly to the pre-feeding level over a period of between 10 and $32 \mathrm{~h}$ (Fig. 1). Rates of filtration also increased immediately 
after the offer of food, declining to pre-feeding levels within 8 to $16 \mathrm{~h}$ (Fig. 1). In all experiments, the excretion rates measured immediately after feeding were not distinguishable from the pre-feeding rates. However, in seven of the experiments with Tetraselmis ( $47 \%$ of the total using this food species) a very marked increase in ammonia excretion occurred between 24 and $30 \mathrm{~h}$ after feeding (Fig. 1). In other experiments with Tetraselmis, and in all seven experiments with Phaeodactylum, no such increases in excretion rate were observed. However, we cannot be sure that they did not occur, due to the difficulties of effectively monitoring ammonia excretion over the long periods

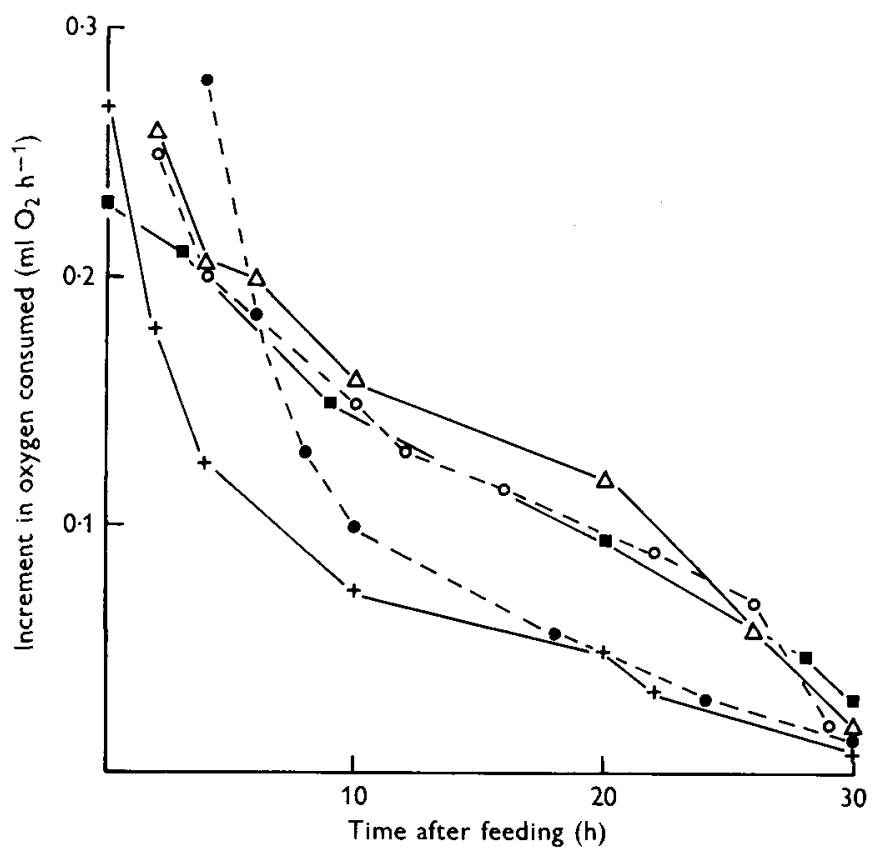

Fig. 2. The increment, above pre-feeding rates, in the rates of oxygen consumption $\left(\mathrm{ml} \mathrm{O}_{2} \mathrm{~h}^{-1}\right)$ by five Mytilus edulis following feeding with Tetraselmis suecica for $1 \mathrm{~h}$.

involved; short periods of increased excretion rate may have been missed. In spite of the varied nature of these results, enough experiments did show both the increase and decline of oxygen consumption, and the enhanced ammonia excretion, to convince us that these were real phenomena associated with feeding.

The curve of decline in the rates of oxygen consumption from the active level following feeding with Tetraselmis suggested that there are at least two components, and this was clarified in five experiments. The increments in oxygen uptake (i.e. $\mathrm{ml}$ of oxygen consumed per hour in excess of the pre-feeding value) in these five experiments are plotted against time in Fig. 2. In six other experiments (a total of 11, or $73 \%$ of the total carried out with Tetraselmis) a similar pattern of at least two components in the decline of oxygen consumption over time after feeding was discernible, but less clearly, due to infrequent measurements of metabolic rate. In the account that follows, therefore, analysis is limited to the five experiments illustrated in Fig. 2. 
Two components to the decline in the oxygen consumption increment with time after feeding were resolved as follows (Fig. 3). The final few measurements of the increment in oxygen uptake (between 22 and $30 \mathrm{~h}$ after feeding) were assumed to represent one-half of a normally distributed set of increment values (the B-component), the other half of which overlapped with previous measurements (the A-component). Resolution of the B-component as a bell-shaped curve, followed by subtraction from the total increment in oxygen consumption, yielded two curves of consumption increment against time (Fig. 3).

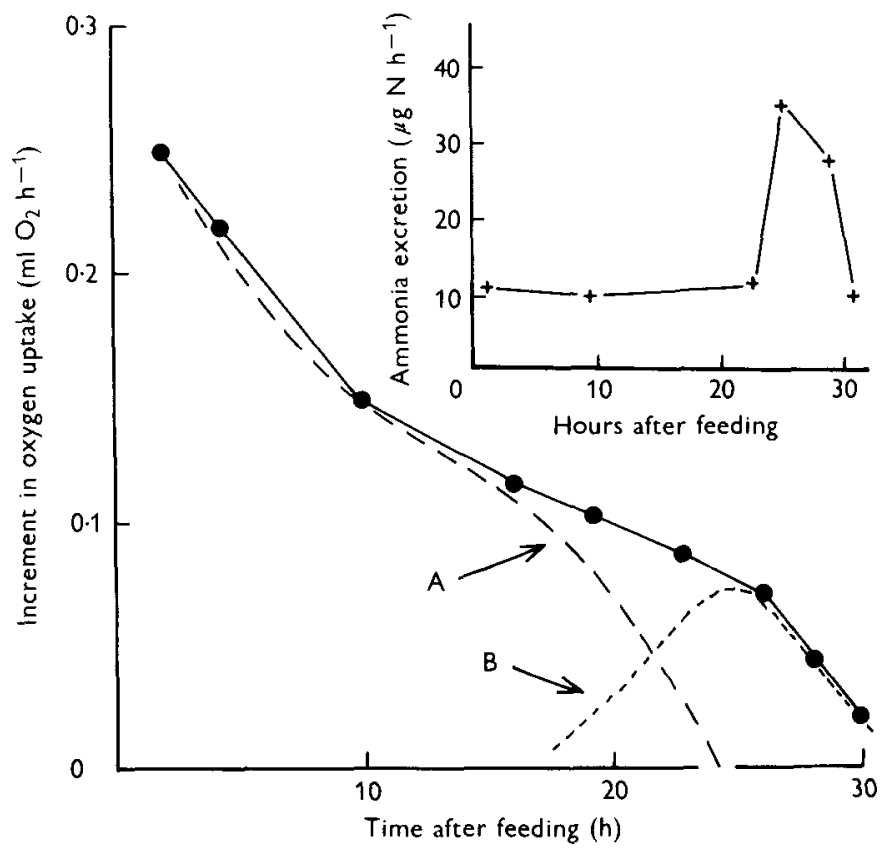

Fig. 3. The increment, above the pre-feeding rate, in oxygen consumption $\left(\mathrm{ml} \mathrm{O}_{2} \mathrm{~h}^{-1}\right)$ by an individual mussel (M. edulis) following feeding with Tetraselmis for $1 \mathrm{~h}$. The curve has been resolved into two components (labelled $A$ and $B$ ) as discussed in the text. Inset: The rate of ammonia- $\mathrm{N}$ excretion $\left(\mu \mathrm{g} \mathrm{NH}_{4} \cdot \mathrm{N} \mathrm{h}^{-1}\right)$ by the same mussel.

In all five experiments under discussion, a transient increase in ammonia excretion was observed, and in all cases this coincided in time with the B-component of the oxygen consumption increment curve (Fig. 3 inset). After feeding with Phaeodactylum, the decline in oxygen consumption occurred more rapidly than when Tetraselmis was the food (Fig. 4); this decline did not resolve into two components, and in no case was increased ammonia excretion after the meal observed.

In Table 1 integrated values for each of the A- and B-components to the oxygen consumption increment are listed for five experiments in which Tetraselmis was the food. The average particle concentration during the $1 \mathrm{~h}$ feeding period was $17 \times 10^{6}$ cells $\mathrm{l}^{-1}$, or $1.12 \mathrm{mg}$ dry weight of cells $1^{-1}$, and the average filtration rate was $2.051 \mathrm{~h}^{-1}$. The ingested ration was therefore $35 \times 10^{6}$ cells or, using constants from Thompson \& Bayne (1974), 13 calories. At an assimilation efficiency of $50 \%$ (Thompson \& Bayne, 1972), this is equivalent to an assimilated ration of 6.5 calories. Thus the A-component of the 
increment in oxygen consumption was equivalent to about $47 \%$, and the B-component to $8 \%$, of the assimilated ration. The coincidence in time of the A-component of the oxygen consumption increment and the filtration rate (Fig. 1) suggests to us that this component represents the 'mechanical cost' of the feeding response. The coincidence in time of the B-component and the pulse of increased ammonia excretion (Fig. 3) suggests that this component represents at least part of the 'physiological cost' of feeding, namely that part that is associated with the deamination of amino acids.

The increases in ammonia excretion above the pre-feeding values were also calculated for five experiments. Values ranged from 10.8 to $42.4 \mu \mathrm{g} \mathrm{NH} . \mathrm{N}$ (mean $29.3 \mu \mathrm{g} \mathrm{N}$ ). We

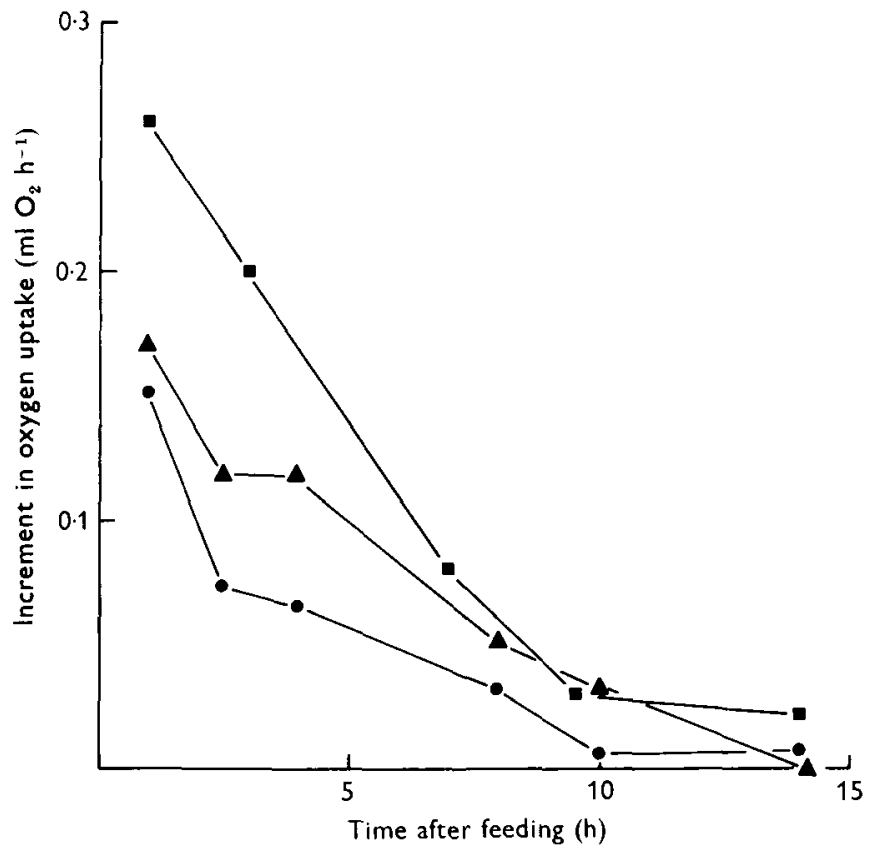

Fig. 4. The increment, above the pre-feeding rates, in the rates of oxygen consumption $\left(\mathrm{ml} \mathrm{O}_{2}\right.$ $\mathrm{h}^{-1}$ ) by Mytilus edulis following feeding with Phaeodactylum tricornutum for $1 \mathrm{~h}$.

TABLE 1. INTEGRATED VALUES FOR THE TWO COMPONENTS (SEE THE TEXT) OF THE INCREASE IN RATE OF OXYGEN CONSUMPTION BY MYTILUS EDULIS FOLLOWING FEEDING FOR $1 \mathrm{~h}$ WITH CELLS OF TETRASELMIS SUECICA (1.12 mg DRY WEIGHT OF ALGAL CELLS PER LITRE)

Average weight of $M$. edulis $=1.33 \pm 0.21 \mathrm{~g}$ of dry flesh. The energy equivalent of the aerobic metabolic rate calculated as $4.75 \mathrm{cals}$ per $\mathrm{ml}$ of oxygen consumed.

\begin{tabular}{ccc} 
Animal & Increment in oxygen uptake $\left(\mathrm{ml} \mathrm{O}_{2}\right)$ \\
\cline { 2 - 2 } no. & A-component & B-component \\
1 & 0.450 & 0.070 \\
2 & 0.705 & 0.065 \\
3 & 0.810 & 0.195 \\
4 & 0.805 & 0.152 \\
5 & 0.435 & 0.085 \\
Mean \pm s.D. & $0.641 \pm 0.186$ & $0.113 \pm 0.057$
\end{tabular}

$\overbrace{\text { A-component }}^{\text {Energy equivalents (cals) }} \begin{array}{cc}\text { B-component } \\ 2.14 & 0.33 \\ 3.35 & 0.31 \\ 3.85 & 0.93 \\ 3.82 & 0.72 \\ 2.07 & 0.41 \\ 3.05 \pm 0.88 & 0.54 \pm 0.27\end{array}$


have measured the nitrogen content of Tetraselmis as $6.2 \times 10^{-6} \mu \mathrm{g} \mathrm{N}$ cell ${ }^{-1}$ (Bayne \& Scullard, 1977). The estimated assimilated ration was therefore equivalent to $108.5 \mu \mathrm{g} \mathrm{N}$ per animal, and the average increase in $\mathrm{NH}_{4} . \mathrm{N}$ excreted represented $27 \%$ of this assimilated nitrogen.

\section{DISCUSSION}

The results of these experiments suggest that the increased activity that follows feeding in Mytilus edulis represents a metabolic cost equivalent to about $24 \%$ of ingested ration (or $47 \%$ of assimilated ration), whereas the costs of assimilation and the metabolism of the assimilated products represents about $4 \%$ of the ingested ration (or $8 \%$ of assimilated ration). Bayne et al. (1976), using a different procedure, estimated for $M$. californianus that the mechanical costs of feeding amounted to approximately $18 \%$, and the physiological cost to $6 \%$, of an ingested ration of mixed algal cells. Our present calculations probably over-estimate the activity cost, since previous studies (Thompson \& Bayne, 1972; Bayne et al. 1973) have shown that if, following a period of starvation, feeding is initiated and then maintained, the rate of oxygen consumption declines from the maximum, or active rate, to a 'routine' value. This over-shoot of the metabolic rate would result in an over-estimate of the activity costs of feeding when food is offered for $1 \mathrm{~h}$ only.

If our supposition, that the coincident pulse of ammonia excretion and second (or B-component) increment in oxygen consumption are causally related, is correct, then the quantities involved should agree with theoretical expectation for the amount of oxygen required to oxidize the free amino acids, namely $4.7 \mu \mathrm{l}$ of oxygen consumed for $1 \mu \mathrm{g}$ of $\mathrm{NH}_{4} . \mathrm{N}$ produced from alanine. Calculating from the observed increments in ammonia- $\mathrm{N}$ excretion, the expected average increment in oxygen consumption is $0.138 \mathrm{ml} \mathrm{O}_{2}$, as compared with the average observed value of $0.113 \mathrm{ml} \mathrm{O}_{2}$ (Table 1). The agreement is surprisingly good, and suggests that the proposed physiological cost of feeding is related in part to the specific dynamic action (SDA) of protein in the diet.

Although the biochemistry of specific dynamic action is not fully understood, it has been associated predominantly with protein metabolism (Krebs, 1964). Deamination of some of the amino acids in the diet leads to the increased production of organic acids (pyruvate, oxaloacetate and $\alpha$-ketoglutarate) which stimulates an acceleration in the tricarboxylic acid cycle. The increased production of adenosine triphosphate that results is then available for protein synthesis. However, the specific dynamic action of food is not a function solely of the protein component; carbohydrates and fat also contribute although to a lesser extent (Harper, 1971).

Values for the SDA (or 'apparent' SDA; Beamish, 1974) in fish vary from 4 to $45 \%$ of the energy ingested by young coho salmon (Averett, quoted by Warren, 1971), 16\% in the alehole (Muir \& Niimi, 1972), 5-24\% for bluegill sunfish (Pierce \& Wissing, 1974) and a mean value of $14 \pm 4 \%$ of energy ingested by the bass (Beamish, 1974). The duration of increased rates of oxygen consumption following feeding varied from 24 to $60 \mathrm{~h}$ in these studies and was found by Beamish (1974) to be dependent on the size of the ration and the weight of the fish.

In our experiments with mussels we recorded an apparent specific dynamic action, related to ammonia excretion, following feeding with the alga Tetraselmis (Prasino- 
phyceae) but not following feeding with Phaeodactylum (Bacillariophyceae). These phytoplankton cells apparently do not normally differ to any large extent in their proximate composition of protein, carbohydrate and fat (Parsons \& Takahashi, 1973) nor in their amino acid compositions (Cowey \& Corner, 1966); we cannot at this time relate differences in the SDA, following feeding with these two species, with any biochemical differences. However, although the total weights of cells fed to the mussels in our experiments were similar $\left(1.12 \pm 0.36 \mathrm{mg}\right.$ algal cells $\left.1^{-1}\right)$, they will have differed in the amounts of organic matter available, due to the presence of a cell wall in Phaeodactylum. In addition, chemical changes that occur during the growth of these cells in artificial culture (Parsons \& Takahashi, 1973) may have contributed to differences between the species as food items for Mytilus.

This work forms part of the experimental ecology programme of the Institute for Marine Environmental Research, a component of the Natural Environment Research Council. It was commissioned in part by the Department of the Environment (contract no. DGR 480/47).

\section{REFERENCES}

BAYNE, B. L., 1973. Aspects of the metabolism of Mytilus edulis during starvation. Netherlands Fournal of Sea Research, 7, 399-410.

Bayne, B. L., Bayne, C. J., Carefoot, T. C. \& Thompson, R. J., 1976. The physiological ecology of Mytilus californianus Conrad. 1. Metabolism and energy balance. Oecologia, 22, 211-228.

BAYNE, B. L. \& ScullaRD, C., 1977. Rates of nitrogen excretion by species of Mytilus (Bivalvia: Mollusca). Fournal of the Marine Biological Association of the United Kingdom, 57, 355369.

BAyne, B. L., Thompson, R. J. \& Widdows, J., 1973. Some effects of temperature and food on the rate of oxygen consumption by Mytilus edulis L. In Effects of Temperature on Ectothermic Organisms (ed. W. Wieser), pp. 181-193. Berlin: Springer-Verlag.

BeAMISH, F. W. H., 1974. Apparent specific dynamic action of largemouth bass, Micropterus salmoides. Fournal of the Fisheries Research Board of Canada, 31, 1763-1769.

COWEY, C. B. \& CORNER, E. D. S., 1966. The amino-acid composition of certain unicellular algae, and of the faecal pellets produced by Calanus finmarchicus when feeding on them. In Some Contemporary Studies in Marine Science (ed. H. Barnes), pp. 225-231. London: George Allen and Unwin.

Grasshoff, K. \& JohannSEn, H., 1972. A new sensitive and direct method for the automatic determination of ammonia in seawater. Fournal du Conseil, 34, 516-521.

HARPER, H. A., 1971. Review of Physiological Chemistry, 13th ed. 564 pp. Los Alctos, California: Lange Medical Publications.

KREBS, H. A., 1964. The metabolic fate of amino acids. In Mammalian Protein Metabolism (ed. H. N. Munro \& J. B. Allison), pp. 125-176. New York: Academic Press.

MUIR, B. S. \& NIIMI, A. J., 1972. Oxygen consumption of the euryhaline fish alehole (Kuhlia sandvicensis) with reference to salinity, swimming, and food consumption. Fournal of the Fisheries Research Board of Canada, 29, 67-77.

Parsons, T. \& TARafashi, M., 1973. Biological Oceanographic Processes. 186 pp. Oxford: Pergamon Press.

PIERCE, R. J. \& Wissing, T. E., 1974. Energy cost of food utilisation in the bluegill (Lepomis macrochirus). Transactions of the American Fisheries Society, 103, 38-45.

Solorzano, L., 1969. Determination of ammonia in natural waters by the phenolhypochlorite method. Limnology and Oceanography, 14, 799-801.

Thompson, R. J. \& BAYNe, B. L., 1972. Active metabolism associated with feeding in the mussel Mytilus edulis L. Fournal of Experimental Marine Biology and Ecology, 8, 191-212. 
Thompson, R. J. \& BAYNE, B. L., 1974. Some relationships between growth, metabolism and food in the mussel, Mytilus edulis. Marine Biology, 27, 317-326.

Warren, C. E., 1971. Biology and Water Pollution Control. 434 pp. Philadelphia: W. B. Saunders. WARREN, C. E. \& Davis, G. E., 1967. Laboratory studies on the feeding, bioenergetics and growth of fish. In The Biological Basis of Freshwater Fish Production (ed. S. D. Gerking), pp. 175-214. Oxford: Blackwell Scientific Publications. 